\title{
EMPIRICALly MEASURING THE IMPACT OF PHOTO ID OVER TIME AND ITS IMPACT ON WOMEN
}

\author{
Michael J. PitTs*
}

\section{INTRODUCTION}

Voter identification laws that require most prospective voters to present government-issued photo identification as a condition of casting a countable ballot continue to be an enormous issue in legislatures and courtrooms across the United States. The 2012 Presidential election cycle featured the high-profile adoption of and litigation related to photo identification laws from Pennsylvania to Texas to South Carolina. ${ }^{1}$ The 2014 mid-term election cycle featured passage of new photo identification laws and litigation from Tennessee to Wisconsin to Arkansas to Virginia to Kansas to Texas (again!). ${ }^{2}$

* Professor of Law and Dean's Fellow, Indiana University Robert H. McKinney School of Law. Enormous thanks go to Erin Radefeld, Georgianna Tutwiler, and Jackie Flint for excellent research assistance.

1. Texas v. Holder, 888 F. Supp. 2 d 113 (D.D.C. 2012); Applewhite v. Commonwealth, No. 330 M.D. 2012, 2012 WL 3332376 (Pa. Commw. Ct. July 16, 2012); South Carolina v. Holder, 898 F. Supp. 2d 30 (D.D.C. 2012).

2. In Arkansas, a state trial court declared that state's law to be in violation of the Arkansas Commissioners. Arkansas State Bd. of Election Comm'rs v. Pulaski Cnty. Election Comm'n, 437 S.W.3d 80 (Ark. 2014). That ruling was stayed pending appeal by the Arkansas Supreme Court. Court Grants Stay in Arkansas Voter-ID Ruling, ARK. ONLINE (Apr. 29, 2014, 4:44 PM), http://www.arkansasonline.com/news/2014/apr/29/state-defends-info-request-voter-idcase/?breaking, archived at http://perma.cc/4X8T-E7K5. A later ruling by the Arkansas Supreme Court struck down Arkansas' law on state constitutional grounds. Martin v. Kohls, 444 S.W.3d 844 (Ark. 2014). In Tennessee, the State Supreme Court rejected several state constitutional challenges to Tennessee's photo identification law. City of Memphis v. Hargett, 414 S.W.3d 88 (Tenn. 2013). In Wisconsin, a federal district court held that Wisconsin's photo identification law violated both the Fourteenth Amendment and section 2 of the Voting Rights Act. Frank v. Walker, Case No. 11CV-01128, 2014 WL 1775432 (E.D. Wis. Apr. 29, 2014). That ruling was subsequently reversed by the Seventh Circuit. Frank v. Walker, 768 F.3d 744 (7th Cir. 2014). The Supreme Court then stayed the Seventh Circuit decision. Frank v. Walker, 135 S. Ct. 7 (2014). Virginia passed a more stringent photo identification law in 2013. Markus Schmidt, Virginia Prepares for New Voter Photo ID Law, RichMOND TimES-DiSPATCH (Dec. 8, 2013, 12:00 AM), http://www.timesdispatch. $\mathrm{com} /$ news/state-regional/virginia-politics/virginia-prepares-for-new-voter-photo-idlaw/article_39b3e5d5-dd31-52f9-ae4f-19d550349ccd.html, archived at http://perma.cc/C395P5XQ. In Kansas, a lawsuit against that state's photo identification law was dropped. John Hanna, 2 Men End Federal Lawsuit Over Kansas Voter ID Law, The WASHIngton Times (Apr. 24, 2014), http://www.washingtontimes.com/news/2014/apr/24/2-men-end-federal-lawsuit-over-kansas-voterid-law/?page=all, archived at http://perma.cc/4HQF-MZSV. A federal district court in Texas enjoined that state's photo identification law on statutory and constitutional grounds. Veasey v. Perry, 2014 WL 5090258 (S.D. Tex. Oct. 9, 2014). The Fifth Circuit stayed that decision pending appeal. Veasey v. Perry, 769 F.3d 890 (5th Cir. 2014).

http://dx.doi.org/10.18060/4806.0006 
Yet there is still very little research related to how photo identification laws actually impact the electorate in terms of the amount of disfranchisement caused by photo identification laws. The lack of research on actual disfranchisement stems from several factors. First, is that photo identification laws are in some ways in their toddler years, having only first appeared anywhere on the landscape in 2006, and only becoming much more widespread after the 2010 mid-term elections. ${ }^{3}$ Second, is that it can be difficult to determine the amount of actual disfranchisement caused by photo identification laws. ${ }^{4}$ Most studies (and expert testimony in litigation) offer statistics about the potential for disfranchisement by attempting to measure how many potential voters do not have valid photo identification. ${ }^{5}$ Other studies purport to measure the turnout effect of voter identification laws but such studies may well be unreliable about gauging a photo identification law's impact. ${ }^{6}$ Other potential studies, such as post-election surveys about the reasons for not voting that specify lack of valid identification as the sole cause of not voting, do not appear to exist.

Perhaps the most definitive way to document actual disfranchisement caused by a photo identification law at a given election is to determine the number of persons who cast a provisional ballot because of a lack of valid photo identification and then did not have that ballot counted. Admittedly, this is an imperfect proxy for the amount of actual disfranchisement in that it may overstate $^{7}$ or (more likely) understate ${ }^{8}$ the amount of disfranchisement that occurred because of a photo identification law at an election. Nevertheless, at the moment, it seems to be the best way to estimate the scope of actual

3. Michael J. Pitts, Photo ID, Provisional Balloting, and Indiana's 2012 Primary Election, 47 U. Rich. L. REV. 939, 939-40 (2013) [hereinafter Pitts, Photo ID].

4. Trymaine Lee, Voter ID Laws Could Disenfranchise 1 Million Young Minority Voters: Study, HufFInGTON Post (Sept. 12, 2012, 6:57 PM), http://www.huffingtonpost.com/2012/09/12/ voter-id-laws-minorities_n_1878893.html, archived at http://perma.cc/UL6Z-X8LV (indicating the hypothetical nature of positions on disenfranchisement).

5. See, e.g., Expert Report Submitted on Behalf of Plaintiffs at 2, Applewhite v. Commonwealth, No. 330 M.D. 2012, 2012 WL 3332376 (Pa. Commw. Ct. July 16, 2012).

6. See generally Robert S. Erickson \& Lorraine Minnite, Modeling Problems in the Voter Identification -Voter Turnout Debate, 8 ELECTION L.J. 85, 87 (2009). See also Jack Citrin et al., The Effects of Voter ID Notification on Voter Turnout: Results from a Large-Scale Field Experiment, 13 ELECTION L.J. 228, 229 (2014) (describing problems with inferring the impact of photo identification requirements through studies of turnout).

7. For instance, considering a provisional ballot cast and not counted because of a lack of valid photo identification as amounting to disfranchisement relies upon the assumption that the person casting the provisional ballot was not committing fraud.

8. To take one example, it is possible that a person was denied the ability to cast a regular ballot because of a lack of valid photo identification but the person decided not to complete a provisional ballot. See Kay Campbell, Voter fraud? 92-year-old Great-Grandmother's Expired Driver's License Unacceptable for Voter ID, AL.COM (June 3, 2014, 2:48 PM), http://blog.al.com/ breaking/2014/06/voter_fraud.html, archived at http://perma.cc/7WGN-XJ25 (relating story of prospective voter who lacked photo identification and who declined filling out a provisional ballot). 
disfranchisement caused by photo identification laws.

The research presented here is part of a series of studies related to the impact of Indiana's photo identification law during the two presidential election cycles at which it has been implemented-2008 and 2012. ${ }^{9}$ This Article tracks the number of provisional ballots cast and not counted because of a lack of voter identification at Indiana's 2012 general election. Importantly, this Article also addresses a relatively new argument that became prominent during the run-up to the 2012 presidential election - the idea that photo identification laws disparately disfranchise female voters. This Article addresses that argument by tracking the gender of those persons who cast provisional ballots due to a lack of valid photo identification-something that, to the best of this author's knowledge, has not been previously done anywhere in the literature. ${ }^{10}$

While the research presented here allows for several conclusions, the most important of those conclusions are as follows. First, Indiana's photo identification law appears to have a relatively small (in relation to the total number of ballots cast) overall actual disfranchising impact on the electorate. Second, Indiana's photo identification law's actual disfranchising impact seems to be headed in a downward direction when one compares data from the 2008 general election to the 2012 general election. Third, Indiana's photo identification law appears to have a disparate impact on women.

The first part of this Article provides background on Indiana's photo identification law and the basics of this research. The second part of the Article presents data and discussion of the lessons that can be learned from that data in relation to the photo identification law in general. The last part of the Article presents data and discussion related the Indiana photo identification law's disparate impact on women.

\section{INDIANA'S PHOTO IDENTIFICATION LAW AND RESEARCH BASICS}

The picayune details of Indiana's photo identification law have been related extensively elsewhere. ${ }^{11}$ Thus, this Article will not rehash the extensive

9. These studies include: Michael J. Pitts, Empirically Assessing the Impact of Photo Identification at the Polls Through an Examination of Provisional Balloting, 24 J. OF L. \& Politics 475 (2008) [hereinafter Pitts, Empirically Assessing]; Michael J. Pitts \& Matthew D. Neumann, Documenting Disfranchisement: Voter Identification During Indiana's 2008 General Election, 25 J. OF L. \& Politics 329 (2009) [hereinafter Pitts \& Neumann, Documenting Disfranchisement]; Pitts, Photo ID, supra note 3.

10. W. Gardner Selby, No Evidence for Claim That Texas Voter ID Law Tries to Disenfranchise Women and Defeat Wendy Davis, PolitiFact TeXas (Oct. 31, 2013, 2:27 PM), http://www.politifact.com/texas/statements/2013/oct/31/democratic-governors-association/noevidence-behind-claim-2011-voter-id-law-came-be/, archived at http://perma.cc/LQ2Q-2N8H (citing expert on photo identification from the Brennan Center as being unaware of research related to photo identification's impact on women).

11. For a more detailed description of the intricacies of Indiana's photo identification law, see Antony Page \& Michael J. Pitts, Poll Workers, Election Administration, and the Problem of 
intricacies of Indiana's photo identification law except as necessary to understanding this research, the law's impact, and potential policy changes. That said, a basic understanding and description of Indiana's photo identification law is warranted.

Indiana's photo identification law requires persons who present themselves at a polling place on election day to provide government-issued photo identification. ${ }^{12}$ The photo identification provided by the prospective voter must: (1) Have been issued by the State of Indiana or the federal government; (2) Have an expiration date and be unexpired or only very recently expired; and (3) Have a name on the identification that "conforms" to the name of the prospective voter in the poll book. ${ }^{13}$ The three basic forms of identification most likely to meet this requirement are an Indiana driver's license, an Indiana state identification card, and a United States passport. ${ }^{14}$ In addition, photo identifications issued by the military without an expiration date also suffice to meet the law's requirements. ${ }^{15}$ Moreover, the State of Indiana provides free photo identifications for voting purposes to those persons who cannot afford the fee for acquiring state identification. $^{16}$

Indiana's photo identification law establishes a system for dealing with a person who appears at the polls without a valid photo identification - that person may cast a provisional ballot. ${ }^{17}$ After casting a provisional ballot, the person then has ten days after the election to return to the local election office and take one of two alternative steps to validate the provisional ballot. ${ }^{18}$ The first alternative is to show a valid photo identification. ${ }^{19}$ The second alternative is to sign an affidavit stating that the person cannot secure a free, valid photo identification without payment of a fee (i.e., for a birth certificate needed to obtain a State identification card) or that the person has a religious objection to being photographed. ${ }^{20}$

While the law generally requires every person voting at an election to present a valid photo identification, there are several exceptions or what might be termed "work-arounds" that allow persons without a valid photo identification to cast a countable ballot. Perhaps the most significant of these work-arounds is that a

Implicit Bias, 15 MICH. J. OF RACE \& LAW 1, 14-20 (2009) and Pitts, Empirically Assessing, supra note 9 , at $482-85$.

12. IND. CODE $\S 3-11-8-25.1$ (a) (2014).

13. Id. § 3-5-2-40.5.

14. Id. $\S 3-11.7-5-2.5(\mathrm{a})(1)$.

15. Id. $\S 3-5-2-40.5(\mathrm{~b})$.

16. Obtaining a Photo ID, INDIANA ELECTION DIV., http://www.in.gov/sos/elections/ 2625.htm (last visited June 25, 2014), archived at http://perma.cc/GS3P-SVHT (providing information about obtaining a free photo identification for voting purposes).

17. IND. CODE $\S 3-11.7-5-2.5$ (2014).

18. Id. §3-11.7-5-1(b) (ten-day period); id. § 3-11.7-5-2.5(a) (appearance before circuit court clerk or county election board).

19. Id. § 3-11.7-5-2.5(b).

20. Id. $\S 3-11.7-5-2.5(\mathrm{c})$. 
person who casts an absentee ballot by mail does not need to present photo identification. ${ }^{21}$ While not all registered voters in Indiana have the ability to cast an absentee ballot by mail, any registered voter who is aged sixty-five or older or who is disabled may do so. ${ }^{22}$ In addition, persons whose election-day polling place is located in the nursing home in which they reside also do not need to show photo identification on election day. ${ }^{23}$

In addition to Indiana's photo identification requirement, one other identification requirement in Indiana merits attention-the identification requirement mandated by the Help America Vote Act ("HAVA"). ${ }^{24}$ The HAVA identification requirement applies to a specific subcategory of voters-persons who have registered to vote by mail, who have not previously voted in a federal election within Indiana, and who have not previously provided proof of identification as part of their registration application. ${ }^{25}$ The HAVA identification requirement is different, though, from the photo identification requirement because the HAVA requirement can be fulfilled using non-photo forms of identification. ${ }^{26}$ For this reason, it is possible for a prospective voter to be able to satisfy the HAVA identification requirement but not Indiana's photo identification requirement. To make matters even more confusing, the HAVA identification requirement can also be satisfied by presentation of a "current and valid photo identification." 27 However, Indiana's photo identification requirement does not require the photo identification to be current. ${ }^{28}$ Thus, it is also possible for a prospective voter who has a government-issued photo identification to be able to satisfy Indiana's photo identification requirement but not the HAVA identification requirement.

The fact that persons who lack valid photo identification at the polling place on election day can cast a provisional ballot provides one means to assess the impact of Indiana's photo identification law on the electorate and forms the basis for this research. Following the 2012 general election, each of Indiana's ninetytwo counties was contacted and asked to provide all of the documents related to provisional balloting. ${ }^{29}$ In addition, to ensure each county was providing a

21. Id. § 3-11-10-24(c) (requirements for voting absentee by mail).

22. Id. $\S 3-11-10-24(4)-(5)$.

23. Id. § 3-11-8-25.1(e).

24. Help America Vote Act, 52 U.S.C. § 21083 (2014).

25. Id. $\S 21083(\mathrm{~b})$.

26. Id. $\S 21083(\mathrm{~b})(2)(\mathrm{A})(\mathrm{ii})(\mathrm{I})-(\mathrm{II})$ (allowing "a copy of a current utility bill, bank statement, government check, paycheck, or other government document that shows the name and address of the voter" to satisfy the HAVA identification requirement).

27. 42 U.S.C. $\S 15483(b)(2)(A)(i i)$ (2014).

28. See supra notes 12-14 and accompanying text.

29. Three documents related to provisional balloting were requested from each county: the PRE-4, PRO-10, and PRO-2. The PRE-4 is filled out by both the prospective voter and poll worker and contains a box for the poll worker to indicate the reason why (e.g., a lack of valid photo identification) a provisional ballot was cast. The PRO-10 form is filled out by a person who cast a provisional ballot due to a lack of valid photo identification when returning to the county election 
relatively ${ }^{30}$ complete set of provisional balloting documents, a form on which the counties reported the number of provisional ballots cast and counted was gathered from the Indiana Secretary of State's office. ${ }^{31}$

After gathering provisional balloting documents from ninety-one of Indiana's ninety-two counties, ${ }^{32}$ the documents were analyzed to determine the following items of interest: ${ }^{33}$ (1) The number of provisional ballots cast in each county; (2)

office after election day to validate a provisional ballot. The PRO-2 form is a document where the county election board indicates whether a provisional ballot has been counted or not counted. To view copies of these forms, see Pitts, Empirically Assessing, supra note 9, at 514-18. The requests made for these documents often necessitated follow up to ensure county election offices were providing the most complete set of provisional balloting paperwork available.

30. I use the term "relatively" because in some instances the documents each county actually possesses related to provisional ballots do not exactly correspond to what the county reported to the Secretary of State. However, most of the time, the discrepancies are relatively small. For instance, the counties provided documents that amounted to a total of 4869 provisional ballots at the 2012 general election whereas the counties reported 5189 total provisional ballots to the Secretary of State. The greatest discrepancies (in terms of raw numbers) between reports to the Secretary of State and the actual paperwork provided came in Clark, Elkhart, Lake, Marion, Porter, Vanderburgh, and Vigo Counties. But, again, even these slight discrepancies (reported infra in Appendix A) seem unlikely to impact the macro-level findings of this research.

31. The form obtained from the Secretary of State is known as a CEB-9 form. The CEB-9 is a post-election report filed with the Secretary of State by each county that provides basic data about the election. Pitts, Photo ID, supra note 3, at 947-48. For purposes of this study, the CEB-9 form contains three important pieces of information: the total ballots cast, the total provisional ballots cast, and the total provisional ballots counted. Id. CEB-9 forms were gathered from ninety counties. Two counties (Jasper and LaGrange) did not file a CEB-9 form with the Secretary of State.

32. Crawford County refused to provide its provisional balloting documents. However, it would not appear that the lack of documents from Crawford County would make much difference to this research as Crawford County reported only five total provisional ballots on its CEB-9. See infra Appendix A.

33. It is worth noting that the Election Assistance Commission ("EAC") provides some data for provisional balloting and provisional ballots related to Indiana's photo identification law in their 2012 Election Administration and Voting Survey. ELECTION ADMIN. COMM'N, 2012 ELECTION ADMIN. AND VOTING SURVEY 48 (2013), available at http://www.eac.gov/assets/1/Page/990050\%20EAC\%20VoterSurvey_508Compliant.pdf, archived at $\mathrm{http}: / /$ perma.cc/CPS8-WHMB. That data is fairly accurate and consistent with this research in regard to the overall number of provisional ballots cast and the overall number of provisional ballots counted at Indiana's 2012 general election. See id. at 48 (reporting 4801 total provisional ballots and 804 counted provisional ballots). However, the EAC differs significantly when it comes to the number of provisional ballots rejected because of a lack of voter identification. See id. at 52 (reporting 452 provisional ballots rejected for lack of sufficient identification). Moreover, the EAC data does not appear to provide the number of voter identification provisional ballots that were counted.

The discrepancy in the data is undoubtedly due to the different methodology used by the EAC for its data collection than the methodology used here. This research relies on provisional ballot 
The number of provisional ballots counted in each county; (3) The number of provisional ballots cast due to a lack of photo identification in each county; (4) The number of provisional ballots cast due to a lack of photo identification counted in each county; (5) The number of provisional ballots cast due to a lack of HAVA-related identification in each county; and (6) The number of provisional ballots cast due to a lack of HAVA-related identification counted in each county. ${ }^{34}$ With this data, it then becomes possible to get a sense of the impact of the photo identification law on an election in Indiana. In addition, this data can also be compared with similar data from Indiana's 2008 general election to assess the impact of the photo identification law in Indiana over time.

\section{MEASURING THE IMPACT OF INDIANA's PHOTO IDENTIFICATION LAW}

The results of the research from the 2012 general election are displayed in Table A. Table A also includes a comparison of those results with data previously obtained from the 2008 general election. Discussion of these results follows. In addition, individual data for all ninety-two of Indiana's counties is included in Appendix A.

documents collected from every Indiana county and an independent review of those documents. The EAC's research relies on surveys of the states. Id. at 4-5 (detailing survey methodology). Reliance on collection of data by survey of the states leads to under-reporting in relation to categorizing the various reasons for why a provisional ballot was cast and/or not counted. $I d$. at 56 (showing 3041 uncounted provisional ballots as "not categorized").

34. Classifying provisional ballots as related to the photo identification law or even just as counted or not counted involves mostly science, but also a dash of art. The provisional balloting documents in Indiana could fairly be described as cumbersome. Thus, poll workers and even local election boards do not always complete the documents to perfection. For this reason, it is sometimes unclear why a particular provisional ballot was cast and whether a particular provisional ballot went counted or uncounted.

In generating the data for this research, a fairly conservative approach was adopted in determining what constituted a photo identification or HAVA-related identification provisional ballot and what constituted a provisional ballot that had been counted. This conservative approach meant that unless the provisional ballot documents clearly indicated the reason for the provisional ballot was identification-related and/or clearly indicated the provisional ballot had been counted, the provisional ballot would be characterized as not related to identification and/or not counted. It is unlikely, however, that decisions on the margins involving how to classify provisional ballots would significantly alter the results of this research. 
$\underline{\text { Table A }}$

\begin{tabular}{|c|c|c|}
\hline Category & $\begin{array}{l}2012 \\
\text { General }\end{array}$ & $\begin{array}{l}2008 \\
\text { General }^{35}\end{array}$ \\
\hline Total Ballots $^{36}$ & $2,676,601$ & $2,805,982$ \\
\hline Total Provisional Ballots Cast & 4,869 & 7,094 \\
\hline Total Provisional Ballots Counted & 706 & 2,035 \\
\hline Total ID Provisional Ballots Cast ${ }^{37}$ & 714 & 1,039 \\
\hline Total ID Provisional Ballots Counted ${ }^{38}$ & 69 & 137 \\
\hline $\begin{array}{l}\text { Provisional Ballots Cast as a } \\
\text { Percentage of Total Votes }\end{array}$ & $0.18 \%$ & $0.25 \%$ \\
\hline
\end{tabular}

35. Data from the 2008 general election appears in Pitts \& Neumann, Documenting Disfranchisement, supra note 9, at 352-53.

36. The total number of ballots cast comes from CEB-9 forms filed by counties with the state with two exceptions. The data from Jasper and LaGrange Counties comes from the Indiana Secretary of State's website. Gen. Election Turnout and Registration (Nov. 6, 2012), http://www.in.gov/sos/elections/files/2012_General_Election_Turnout_Report.pdf, archived at http://perma.cc/XH44-HACS.

37. The "Total ID Provisional Ballots Cast" combines the number of photo identificationrelated provisional ballots cast with the number of HAVA identification-related provisional ballots cast. This was done for two reasons. First, data that distinguishes between photo ID-related provisional ballots and HAVA-related provisional ballots cast at the 2008 general election is not available. Pitts \& Neumann, Documenting Disfranchisement, supra note 9, at 342 n.57 (explaining methodology for 2008 empirical study of photo identification). Second, the inclusion of HAVArelated provisional ballots does not likely have much of an impact on the overall results. For instance, at Indiana's 2008 primary election, only forty-seven HAVA-related provisional ballots were cast. $I d$. at 342 n. 58 .

At the 2012 general election, only 129 HAVA-related provisional ballots were cast. And even that number likely overstates the amount of HAVA-related provisional ballots cast because seventysix of these HAVA-related provisional ballots came from a single county - Vanderburgh County - a result that leads me to suspect that poll workers erroneously identified a lack of photo identification as a lack of HAVA identification on the provisional ballot forms.

38. The "Total ID Provisional Ballots Counted" combines the number of photo identificationrelated provisional ballots counted with the number of HAVA-related provisional ballots counted. Including the number of HAVA-related provisional ballots counted does little to change the rate at which identification-related provisional ballots were counted, as only nineteen of the 129 HAVArelated provisional ballots were counted. 


\begin{tabular}{|l|l|l|}
\hline $\begin{array}{l}\text { ID Provisional Ballots Cast as a } \\
\text { Percentage of Total Votes }\end{array}$ & $0.026 \%$ & $0.037 \%$ \\
\hline $\begin{array}{l}\text { ID Provisional Ballots Cast as a } \\
\text { Percentage of Total Provisional Ballots }\end{array}$ & $14.6 \%$ & $14.6 \%$ \\
\hline $\begin{array}{l}\text { Total Provisional Ballots Counted as a } \\
\text { Percentage of Total Provisional } \\
\text { Ballots Cast }\end{array}$ & $14.4 \%$ & $28.7 \%$ \\
\hline $\begin{array}{l}\text { ID Provisional Ballots Counted as a } \\
\text { Percentage of ID Provisional } \\
\text { Ballots Cast }\end{array}$ & $9.6 \%$ & $13.2 \%$ \\
\hline
\end{tabular}

Photo ID actually disfranchises relatively few voters. The data from the 2012 general election seems to confirm several things about the impact of Indiana's photo identification law. First, the 2012 data, particularly when analyzed in conjunction with the 2008 data, suggests that relatively few people are actually disfranchised by the photo identification requirement. At the 2012 general election, only about 650 persons in an electorate of nearly 2.7 million voters did not have a ballot counted because of a problem with voter identification. ${ }^{39}$ That is a very small number in relation to the size of the electorate and not an amount of persons who are likely to make an impact on the outcome of a statewide election. ${ }^{40}$

In fairness, it is certainly true that a study of provisional balloting cannot account for all the disfranchisement caused by a photo identification law. There are undoubtedly other ways that photo identification laws cause disfranchisement, including because poll workers fail to offer a provisional ballot to a prospective voter who does not have valid photo identification or because a prospective voter refuses to engage in the somewhat time consuming process of completing a provisional ballot. There have, however, not been widespread reports or empirical data to support the idea that thousands of provisional ballots are not being cast because of these sorts of occurrences. ${ }^{41}$

39. See supra Table A (showing that out of 714 photo ID provisional ballots cast, sixty-nine were counted).

40. Cf. Nate Cohn, Why Voter ID Laws Will Seldom Swing Elections, N.Y. TIMES, Nov. 20, 2014, at A3 (arguing that voter ID laws “don't make enough of a difference to decide anything but the closest contests, when anything and everything matter.").

41. It may also be the case that a study of provisional ballots overstates the level of disfranchisement occurring because of the inability to present valid photo identification. On one level, it may be that persons who cast provisional ballots because of a lack of valid photo identification and who did not later validate those provisional ballots were committing fraud. However, that seems unlikely because persons committing voter fraud would be utterly foolish to leave a paper trail of the fraud. More likely would be that persons who cast provisional ballots because they lacked valid photo identification actually have valid photo identification and either forgot their identification or just refused to show their photo identification out of opposition to the law. See, e.g., City of Memphis v. Hargett, 414 S.W.3d 88, 94 (Tenn. 2013) (noting that of thirtytwo voters who cast provisional ballots due to a lack of photo identification at the 2012 primary 
Perhaps the strongest possibility for a lack of actual disfranchisement showing up in provisional balloting would be that potential voters remain at home because they know they do not possess a valid photo identification. The theory would be that the photo identification law is well-known among registered voters, some voters who remain at home do not possess or do not have the ability to easily secure a valid photo identification, and, because of their knowledge of these barriers, they sit on the sidelines by not venturing out to the polling place at all.

But the idea that there are tens of thousands or even thousands of persons staying home because they lack valid photo identification seems far-fetched - at least in Indiana. First, these would-be voters would have to know the details of voting rules, and one suspects that many voters are not intimately familiar with polling place processes. Second, if there were thousands of persons staying at home because of a lack of photo identification, an empirical study - for instance a scientifically conducted post-election survey-could be performed to provide a working estimate of how many such persons exist. Yet, to date, no one has placed such a survey in the field in Indiana despite the widespread amount of litigation related to photo identification laws. Third, if such persons existed and numbered in the tens of thousands, one would have expected interest groups opposed to photo identification to have rallied these persons, perhaps to form the basis of a lawsuit. ${ }^{42}$ Finally, there is some evidence that voter knowledge of strict (e.g., photo) voter identification laws may actually increase turnout. ${ }^{43}$ At the end of the day there is currently not any credible empirical evidence for the notion that knowledge of inability to comply with Indiana's photo identification law is keeping Indiana voters away from the polls in droves. ${ }^{44}$ If Indiana's photo

election in Shelby County, twenty had a Tennessee driver's license); Suevon Lee, What Effect, If Any, Did Voter ID Laws Have on the Election?, Pro PublicA (Nov. 15, 2012, 2:34 PM), http://www.propublica.org/article/what-effect-if-any-did-voter-id-laws-have-on-the-election, archived at http://perma.cc/G2JT-D2SE (reporting how one voter in New Hampshire refused to show photo identification as an "act of defiance").

42. While an unsuccessful federal lawsuit was brought against Indiana's photo identification law, that lawsuit was filed prior to implementation of the law. Crawford v. Marion Cnty. Election Bd., 553 U.S. 181, 186-87 (2008). Moreover, that lawsuit was unsuccessful in large part due to the lack of evidence of disfranchisement. $I d$. at 198-203. Presumably the implementation of Indiana's photo identification law over several election cycles presents a renewed opportunity to gather thousands of plaintiffs who are actually disfranchised by the law if those persons actually exist.

43. Citrin et al., supra note 6, at 235, 238 (finding "little support for the hypothesis that notification of ID requirements depresses turnout" and that "experimental results suggest that notifications about voter identification requirements may increase turnout").

44. For additional and more detailed discussion of reasons why Indiana's photo identification law has likely not kept tens of thousands of persons away from the polls, see Pitts \& Neumann, Documenting Disfranchisement, supra note 9, at 343-46.

A national study showed that lack of identification was a contributing factor for not voting for forty-four percent of non-voters who lacked a driver's license in "strict" photo identification states. Charles Stewart III, Voter ID: Who Has Them? Who Shows Them?, 66 OKLA. L. REV. 21, 50 
identification law has not led to widespread disfranchisement, the search then becomes for explanations as to why that is the case. One reason might be that the vast majority of registered voters who are interested in casting a ballot have valid photo identification. ${ }^{45}$ In addition, it is likely that the political market adapts relatively quickly to photo identification laws such that those persons who want to vote either secure a free photo identification from the state or use the ability to vote absentee by mail to cast a ballot. ${ }^{46}$ In relation to the idea that registered voters secure identification, nearly 1.2 million persons have received a free photo identification from the State of Indiana since passage of the photo identification law. ${ }^{47}$ Moreover, political campaigns and non-profit groups may be helping voters get these free photo identifications. ${ }^{48}$ In relation to the idea that voters without valid photo identification are finding ways around the law, the amount of absentee voting in Indiana more than doubled after implementation of the photo identification law. ${ }^{49}$ While it is likely some of this increase in absentee voting is due to greater availability of absentee voting, some of the increase may well be attributable to seniors or other individuals who lack valid photo identification casting absentee ballots by mail — a method of voting that does not

(2013). However, the researcher who reported that statistic urged "extreme caution" because the finding was based on a small number of respondents. Id. Moreover, this research also does not appear to isolate lack of photo ID as the sole factor for not voting. Id.

45. Citrin et al., supra note 6, at 229 ("[T]he vast majority of Americans, including minorities, claim to have necessary identification ...").

46. $C f$. Seth C. McKee et al., Evolution of an Issue: Voter ID Laws in the American States, Prepared for Delivery at the 2013 Annual Meeting of the American Political Science Association 7 (Aug. 29, 2013-Sept. 1, 2013) (transcript available at http://papers.ssrn.com/sol3/papers.cfm? abstract_id=2300630), archived at http://perma.cc/5ZGF-MQTN (“Although political participation is remarkably sensitive to contextual factors such that slight changes to the costs and benefits of voting can clearly move the needle up or down ..., in most settings, voter ID laws will likely have marginal effects on voter participation. Indeed, the findings on the question of whether restrictive voter ID laws actually depress turnout are largely inconclusive.”).

47. Email from Elizabeth Murphy, General Counsel, Indiana Bureau of Motor Vehicles, to Michael Pitts (Jan. 18, 2013) (on file with author) (showing that between 2006 and 2012, Indiana had issued 1,178,394 free IDs).

48. See Michael D. Shear, Obama Campaign Grapples with New Voter ID Laws, N.Y. TIMES (Apr. 29, 2012), http://www.nytimes.com/2012/04/30/us/politics/obama-campaign-confronts-voterid-laws.html?_r=2\&ref=politics\&, archived at http://perma.cc/9NAZ-6WJF; Citrin et al., supra note 6, at 231 (describing efforts by the League of Women Voters to help registered voters secure identification).

49. Indiana's photo identification law was adopted in 2005. S. Enrolled Act 438, Pub. L. No. 109 (2005). Prior to adoption of the law, at the 2004 general election, 260,550 absentee ballots were cast. Indiana Election Division, Indiana Election Results, IN.GOv, http://www.in.gov/sos/ elections/2400.htm (last visited May 7, 2014), archived at http://perma.cc/8E9D-L4N6. After implementation of the law, at the 2008 general election, 662,443 absentee ballots were cast, and at the 2012 general election 590,445 absentee ballots were cast. See id. 
require presentation of a valid photo identification..$^{50}$

One thing that bears acknowledgement is that this research focuses on actual disfranchisement rather than the potential for disfranchisement and that the potential for disfranchisement from a photo identification law may be much higher than actual disfranchisement. For example, a federal district court in Wisconsin enjoined Wisconsin's photo identification law, finding that approximately 300,000 registered voters lacked valid photo identification. ${ }^{51}$ That number, however, likely overstates the amount of actual disfranchisement by quite a lot. For starters, that number was contested by another expert witness who deemed the number of registered voters without a valid photo identification to be closer to 170,000 persons. ${ }^{52}$ Second, even assuming there are 300,000 Wisconsin registered voters without a valid photo identification, it is possible that many of those voters will not cast a ballot. ${ }^{53}$ Third, it is possible that many of those 300,000 registered voters will be able to secure a free photo identification. ${ }^{54}$ Fourth, it is possible that some of those 300,000 registered voters will be able to vote without showing a photo identification through one of the exceptions in the law. ${ }^{55}$

Indeed, it may well be a mistake for opponents of photo identification laws to focus on the potential for disfranchisement rather than actual disfranchisement. Opponents of photo identification laws tend to seize upon the idea that photo identification solves a non-existent problem - voter impersonation fraud (which might also be called "voter identity theft"). They, quite rightfully, justify that position by citing to the lack of evidence of voter impersonation fraud. ${ }^{56}$ But proponents of photo identification laws generally counter that there is the opportunity for voter impersonation fraud through, for example, bloated voter

50. IND. CODE § 3-11-10-24(c) (2014) (requirements for voting absentee by mail).

51. Frank v. Walker, No. 11-CV-01128, slip op. at 23 (E.D. Wis. Apr. 29, 2014) ("I find that approximately 300,000 registered voters in Wisconsin, roughly $9 \%$ of all registered voters, lack a qualifying ID.").

52. Id. at 74 .

53. For instance, a study in North Carolina found that about 319,000 registered voters lacked state-issued photo identification. State Board of Elections, April 2013 SBOE-DMV ID Analysis 6 (April 17, 2013), http://www.democracy-nc.org/downloads/SBOE-DMVMatchMemoApril2013. pdf, archived at http://perma.cc/E6KC-2368; see also Nate Cohn, Finally, Real Numbers on Voter ID, NEw REPUBLIC (July 22, 2013), http://www.newrepublic.com/article/113986/voter-id-northcarolina-law-hurts-democrats, archived at http://perma.cc/PZX3-6W3J. However, only about 138,000 of those voters participated in the 2012 general election, and about sixty-three percent of voters who did not participate in the 2012 general election had not participated in any of the last five general elections. Id.

54. It is worth noting that even if a registered voter secures valid photo identification to prevent disfranchisement, the burden of securing that photo identification adds an additional cost to voting that may not be worth the amount of in-person voter fraud prevented.

55. Frank, slip op. at 5-6 (listing exceptions).

56. Richard L. Hasen, The Voting Wars 6 (2012). 
registration lists. ${ }^{57}$ So, to the extent that opponents of photo identification laws focus on the opportunity for disfranchisement that, at least in this author's view, gives credence to the "opportunity for fraud" arguments from proponents of photo identification laws.

Notably, though, the amount of actual disfranchisement created by a photo identification law may well depend on the nature of the photo identification law adopted. For instance, Indiana's law essentially has a broad exception for voters over the age of sixty-five because those voters can cast an absentee ballot by mail that does not require them to provide photo identification. ${ }^{58}$ In contrast, Wisconsin's photo identification law does not seem to have as broad an exception for elderly voters. ${ }^{59}$ Put simply, all photo identification laws are not created equal and may have different impacts - a point that often gets lost in the broad strokes of the photo identification debate.

But the basic results from Indiana do seem to be consistent with the experience of implementing photo identification laws in other states. Newspaper reports have indicated that in states where photo identification laws have been passed, very few provisional ballots have been cast by voters who lacked valid photo identification. ${ }^{60}$ For example, at the 2012 general election in Tennessee, 674 persons cast provisional ballots because of a lack of photo identification out of 2.45 million ballots cast. ${ }^{61}$ At the 2012 general election in New Hampshire, which was testing its photo identification law, about one percent of voters did not have or refused to show a valid photo identification. ${ }^{62}$ At the 2012 primary election in Alabama, 282 ballots went uncounted because voters lacked photo identification. ${ }^{63}$ Results from several elections in Georgia between 2007 and

57. Crawford v. Marion Cnty. Election Bd., 553 U.S. 181, 194-98 (2008) (plurality opinion) (discussing Indiana's fraud prevention justification for its photo identification law); see also Michael D. Gilbert, The Problem of Voter Fraud, COLUM. L. REV. (forthcoming 2015), available at http://papers.ssrn.com/sol3/papers.cfm?abstract_id=2488645.

58. See supra note 16 and accompanying text.

59. WIS. STAT. $\S \S 6.86(2), 6.875$ (only allowing elderly voters who are indefinitely confined to their homes or certain care facilities to vote absentee without providing photo identification); see also Frank, slip op. at 6 . For other differences between Indiana's and Wisconsin's law, see Frank v. Walker, 768 F.3d 744, 746 (7th Cir. 2014).

60. See generally David Brooks, About 1 Percent of NH Voters Didn't Show ID on Election Day; Letters to Be Sent Out, NASHUA TELEGRAPH (Nov. 27, 2012), http://www.nashuatelegraph. com/print/?sid=2870836, archived at http://perma.cc/R32X-A9DM; Suevon Lee, What Effect, If Any, Did Voter ID Laws Have on the Election, ProPublica (Nov. 15, 2012, 1:34 PM), http://www.propublica.org/article/what-effect-if-any-did-voter-id-laws-have-on-the-election, archived at http://perma.cc/G2JT-D2SE; Shannon McCaffrey, Voter Turnout Surges Amid FiveYear ID Law, ATL. J-CONST., Sept. 3, 2012, at 1A.

61. Lee, supra note 60.

62. Brooks, supra note 60.

63. Martin J. Reed, Alabama's Voter ID Law Blamed for at Least 282 Ballots Uncounted in Primary, AL.COM (Sept. 3, 2014, 4:45 PM), http://www.al.com/news/birmingham/index.ssf/2014/ 09/alabamas_voter_id_law_blamed_f.html, archived at http://perma.cc/YL32-RJ3V. To be fair, 
2012 also produced similar data. ${ }^{64}$

At the end of the day, though, while there is very strong evidence to think photo identification laws cause some actual disfranchisement within the citizenry, at the moment there is not compelling evidence to demonstrate that the amount of actual disfranchisement is in the hundreds, or even tens, of thousands within Indiana. And, to the extent that Indiana's law serves as a model for other photo identification laws being adopted, this may tend to indicate those other laws will not lead to massive disfranchisement within those states. ${ }^{65}$

Provisional balloting "rescues" very few photo identification provisional ballots. After studying several elections at which Indiana's photo identification law has been in place, it has become clear that if a prospective voter casts a provisional ballot due to a lack of valid photo identification, there is an enormously high likelihood that the ballot will ultimately go uncounted. In the 2012 general election, less than ten percent of provisional ballots cast due to a lack of voter identification were ultimately counted. ${ }^{66}$ This small number is consistent with findings from the 2008 general election, and from primary elections in 2008 and 2012. ${ }^{67}$ This small number is also consistent with empirical evidence found elsewhere. ${ }^{68}$

The lack of provisional ballots counted after being cast for lack of valid photo identification may indicate that the photo identification law should be changed to increase the chances of such a ballot being counted. ${ }^{69}$ Currently, the burden of validating a provisional ballot lies with the voter who has to make an additional post-election trip to the local election office. ${ }^{70}$ Instead, perhaps the burden of determining whether to count a provisional ballot cast by a person without valid photo identification should be placed more on election administrators rather than registered voters themselves. For instance, after the election, an election official could call the phone number listed on the voter registration to confirm that the

this statistic only represented data from 49 of Alabama's 67 counties. Id.

64. McCaffrey, supra note 60 (noting that over several elections at which about 13.6 million total votes were cast, only 1586 ballots went uncounted because of Georgia's photo identification law).

65. Pitts \& Neumann, Documenting Disfranchisement, supra note 9, at 331 (noting how Indiana's photo identification law may serve as a model for other such laws).

66. Supra Table A.

67. See generally Pitts \& Neumann, Documenting Disfranchisement, supra note 9; Pitts, Empirically Assessing, supra note 9; Pitts, Photo ID, supra note 3.

68. See City of Memphis v. Hargett, 414 S.W.3d 88, 94 (Tenn. 2013) (reporting that at the 2012 primary election in Shelby County, Tennessee, thirty-two persons cast provisional ballots due to a lack of a valid photo identification and only four of those provisional ballots were counted).

69. If the provisional ballot process is essentially meaningless then perhaps the provisional balloting process should be eliminated when it comes to casting a ballot because of a lack of valid photo identification. However, such a change in the law would seem to violate HAVA. HAVA requires a provisional ballot be offered to a person whose name does not appear on the poll book or who is declared by an election official as ineligible to vote. 42 U.S.C. $§ 15482$ (a) (2014).

70. See Page \& Pitts, supra note 11 and accompanying text. 
person who presented himself or herself at the polling place was not an impersonator and also visit that person's physical address to secure such confirmation. ${ }^{71}$ This would not seem to be much of a post-election burden on election administrators, as most counties have only a handful of provisional ballots related to photo identification. The main point, though, is that Indiana law should probably be amended to provide a better way of handling these provisional ballots so that more of them get counted.

As all provisional ballots go, so go voter identification-related provisional ballots. In general, the rate of provisional balloting fell from the 2008 to 2012 general election. ${ }^{72}$ At the 2008 general election, the percentage of provisional ballots in relation to the total votes cast was $0.25 \%$; at the 2012 general election, the percentage of provisional ballots in relation to the total votes cast was $0.18 \%{ }^{73}$ The number of identification-related provisional ballots also fell. ${ }^{74}$ However, the number of identification-related provisional ballots in relation to the total number of provisional ballots cast remained steady at $14.6 \%$ at each election. ${ }^{75}$

The decrease in the rate of identification-related provisional ballots could be the result of many different things. It is possible that the decrease was caused by more registered voters without valid photo identification securing valid identification. The decrease might also be caused by more registered voters without valid photo identification using absentee balloting by mail (which does not require valid photo identification). On the other hand, it is also possible the decrease was caused by voters without valid photo identification staying home because of the foreknowledge that they would not be able to cast a countable ballot due to a lack of valid photo identification. Thus, at the end of the day, it is not clear whether the lower number of identification-related provisional ballots at the 2012 election reflects a lower amount of actual disfranchisement or just a different type of actual disfranchisement.

\section{THE GENDER IMPACT OF PHOTO IDENTIFICATION}

Photo identification laws have been adopted and implemented for nearly a decade and the arguments against photo identification laws have generally solidified. However, in the past couple of years, a different argument moved to the forefront of the photo identification debate. That argument is that photo

71. I suppose that such a confirmation would not prevent voter fraud that occurred by a person who (1) submitted a fake registration form and then (2) cast a provisional ballot under that fake registration. However, it seems unlikely that persons knowingly committing voter fraud would create a paper trail of that fraud by casting a provisional ballot, providing a phone number to be contacted, and then actually conversing or meeting with an election official. See supra note 28.

72. See supra Table A.

73. Id.

74. Id.

75. Id. 
identification laws have a disproportionate impact on women. ${ }^{76}$

The argument that women will be disproportionately disfranchised by photo identification laws focuses largely on the potential for a mismatch between the name on the identification and the name on the poll books. The notion is that women are highly likely to change their name after marriage or divorce. ${ }^{77}$ Because women are more likely to change their names than men, the name on the identification may not exactly match the name on the registration list, and poll workers may deny those women the ability to cast a regular ballot. ${ }^{78}$

Most photo identification laws, however, have a process that allows for persons who have had their name changed to vote a regular ballot. For instance, in Texas, if a voter's name on her identification does not match the name in the poll book, the voter may sign an affidavit on the poll book asserting she is the same person. ${ }^{79}$ Importantly for our purposes, in Indiana, a person whose name has changed can indicate that name change on the poll book and cast a regular ballot. ${ }^{80}$ In short, if poll workers implement the laws as written, name changes due to marriage or divorce should not be a problem for women. ${ }^{81}$

But proper implementation of photo identification laws by poll workers may be a big if. Poll workers may not implement the name-change rules properly for numerous reasons, including lack of knowledge or training. ${ }^{82}$ Put simply, poll worker error in relation to name changes could disproportionately impact women because they are more likely to have name changes than men.

One possible way of assessing whether photo identification laws disproportionately impact women - due to name changes or otherwise-would be to examine whether women are overrepresented in the number of provisional ballots cast and not counted due to a lack of identification. If women are more likely to be disfranchised by problems with the photo identification law-particularly those related to name changes - one might expect that more women in relation to their proportion of the electorate generally would cast a provisional ballot because of a photo identification problem.

76. Barbara Arnwine \& Eleanor Smeal, The War on Voting is a War on Women, MSNBC (Oct. 20, 2013, 5:59 PM), http://www.msnbc.com/msnbc/the-war-voting-war-women, archived at http://perma.cc/P4T2-VN59; Selby, supra note 10 (noting that very little of the discussion relating to passage of Texas' photo ID law in 2011 related to the potential for disfranchising women).

77. Renee Davidson, How Voter ID Laws Disproportionately Impact Women-And What We're Doing About It, LEAGUE OF WOMEN VOTERS (Jan. 2, 2014), http://www.lwv.org/blog/howvoter-id-laws-disproportionately-impact-women- $\% \mathrm{E} 2 \% 80 \% 93$-and-what-we $\% \mathrm{E} 2 \% 80 \% 99 \mathrm{re}$-doingabout-it, archived at http://perma.cc/9JXB-E37T\#_blank.

78. Martha T. Moore, State Voter ID Laws Snare Women with Name Changes, USA ToDAY (Oct. 30, 2013, 7:05 PM), http://www.usatoday.com/story/news/politics/2013/10/30/voter-id-lawsname-changes/3315971/, archived at http://perma.cc/D72V-AACG\#_blank.

79. $I d$.

80. For a detailed explanation of the issue in Indiana, see Page \& Pitts, supra note 11, at 18 n.96.

81. See id.

82. Moore, supra note 78 . 
Unfortunately, Indiana's provisional balloting paperwork does not contain information to explicitly indicate the gender of the person casting the provisional ballot. Thus, to determine the gender of the persons who cast provisional ballots because of a lack of photo identification at the 2012 general election, the documentation accompanying each provisional ballot had to be reviewed and categorized by name. The categorizing of names was done initially by two research assistants and then reviewed by the author. In almost all instances, categorization of the gender of the person casting the provisional ballot was done by first name. In a few instances, the combination of a first and middle name was used to make the determination. In about a handful of instances, the name was ambiguous but some other notation on the materials indicated gender. A complete list of how the names were categorized appears as Appendix B to this article. ${ }^{83}$ The results appear in Table B.

$\underline{\text { Table B }}$

\begin{tabular}{|l|l|l|l|l|}
\hline Category & Total & Male & Female & Undetermined \\
\hline Turnout $^{84}$ & $2,801,000$ & $\begin{array}{l}1,331,000 \\
(47.5 \%)\end{array}$ & $\begin{array}{l}1,470,000 \\
(52.5 \%)\end{array}$ & N/A \\
\hline $\begin{array}{l}\text { Photo ID Provisional } \\
\text { Ballots }\end{array}$ & 585 & $216(36.9 \%)$ & $310(52.9 \%)$ & $59(10.0 \%)$ \\
\hline $\begin{array}{l}\text { Photo ID Provisional } \\
\text { Ballots with Gender } \\
\text { Determined }\end{array}$ & 526 & $216(41.0 \%)$ & $310(58.9 \%)$ & N/A \\
\hline Photo ID Counted & 50 & $15(30.5 \%)$ & $28(56 \%)$ & $7(14 \%)$ \\
\hline $\begin{array}{l}\text { Photo ID Counted } \\
\text { with Gender } \\
\text { Determined }\end{array}$ & 43 & $15(34.9 \%)$ & $28(65.1 \%)$ & N/A \\
\hline
\end{tabular}

While not definitive, the data suggests that photo identification laws do have a disparate disfranchising impact on women. Women made up $52.5 \%$ of the electorate at the 2012 general election. ${ }^{85}$ However, they comprised $58.9 \%$ of the photo identification provisional ballots that were categorized as either female or male. ${ }^{86}$ And while female provisional ballots were slightly more likely to be

83. The categorization of names by gender is an imperfect science. However, it seems unlikely that the imperfections would be more than slight and that the slight imperfections would significantly changes the analysis.

84. For purposes of studying gender disparities, data on turnout was obtained from the United States Census. United States Census, Voting and Registration, http://www.census.gov/hhes/www/ socdemo/voting/publications/p20/2012/tables.html (last visited June 17, 2014), archived at http://perma.cc/LR6S-J4RF (Table 4b).

85. See Table B.

86. There is no reason to think that the less than ten percent of provisional ballots that could 
counted than male ballots - even considering this slight differential, women disproportionately have their provisional ballots rejected due to Indiana's photo identification law.

Interestingly, the data also suggests that the HAVA identification requirement has a similar disparate disfranchising impact on females. As the data in Table C shows, women comprised more than sixty percent of the HAVA identification provisional ballots that were categorized as either male or female. And, again, while female HAVA identification provisional ballots were slightly more likely to be counted than their male counterparts, that slight differential does not lessen the disfranchising impact by very much. ${ }^{87}$

$\underline{\text { Table C }}$

\begin{tabular}{|l|l|l|l|l|}
\hline Category & Total & Male & Female & Undetermined \\
\hline Turnout & $2,801,000$ & $\begin{array}{l}1,331,000 \\
(47.5 \%)\end{array}$ & $\begin{array}{l}1,470,000 \\
(52.5 \%)\end{array}$ & N/A \\
\hline HAVA Provisionals & 129 & $47(36.4 \%)$ & $74(57.3 \%)$ & $8(6.2 \%)$ \\
\hline $\begin{array}{l}\text { HAVA Provisionals } \\
\text { with Gender } \\
\text { Determined }\end{array}$ & 121 & $47(38.8 \%)$ & $74(61.1 \%)$ & N/A \\
\hline HAVA Counted & 19 & $6(31.6 \%)$ & $11(57.9 \%)$ & $2(10.5 \%)$ \\
\hline $\begin{array}{l}\text { HAVA Counted } \\
\text { with Gender } \\
\text { Determined }\end{array}$ & 17 & $6(35.3 \%)$ & $11(64.7 \%)$ & N/A \\
\hline
\end{tabular}

At the end of the day, this research provides some empirical evidence suggesting that photo identification laws will have a more disfranchising impact on women than men. ${ }^{88}$ Of course, this study only comprises one election with one state's photo identification law, so further research at other elections and in other states would be needed to more definitively prove the disparate impact.

not be categorized as male or female would substantially change the results. Even if every single one of those ballots had been cast by a male, women would still be disparately impacted - though less so. Indeed, a review of the names listed as "Undetermined" in Appendix B makes it seem much more likely that the provisional ballots with undetermined names would break along the same lines as the provisional ballots where gender could be identified.

87. Of course, if my theory is correct about Vanderburgh County misclassifying photo identification-related provisional ballots as HAVA identification-related provisional ballots, see supra note 33, then the data related to HAVA may be less useful.

88. Of course, it is possible the disparate impact would not exist if we could account for other ways photo identification laws disfranchise voters. For instance, perhaps men are more likely than women to stay away from the polls in their entirety because they know they do not have a valid photo identification. Or, maybe men who lack valid photo identification are more likely than women to refuse to undergo the provisional balloting process. However, to the best of my knowledge, there is no obvious reason to think either of these scenarios is correct. 
Moreover, this research does not demonstrate the reasons why women would be more disparately impacted than men by a photo identification law but the theory that name changes are more prevalent among women than men might provide a reasonable explanation.

\section{CONCLUSION}

Photo identification laws are still relatively new on the landscape and not all photo identification laws operate in the same manner. However, in Indiana, a state where a photo identification law has been operating over several election cycles, it appears that the photo identification law causes the actual disfranchisement of relatively few voters. That said, some disfranchisement occurs and, to the extent that disfranchisement occurs, this research suggests that women are disproportionately disfranchised.

Yet significant work remains to be done in this area. Other state's photo identification laws need to be tracked over several election cycles and other state's need to be analyzed to determine if their laws also suggest a gender-based disparity of disfranchisement. Most importantly, other research needs to more definitively pin down just how many persons are staying away from the polls because they know they cannot meet a photo identification requirement. Only with additional research in all these areas can the full extent of disfranchisement of photo identification laws be known. 
Appendix A

\begin{tabular}{|c|c|c|c|c|c|c|c|c|c|}
\hline County & $\begin{array}{c}\text { Total } \\
\text { Ballots }\end{array}$ & $\begin{array}{c}\text { CEB-9 } \\
\text { Total } \\
\text { Provisionals }\end{array}$ & $\begin{array}{c}\text { CEB-9 } \\
\text { Counted } \\
\text { Provisionals }\end{array}$ & $\begin{array}{c}\text { Documents } \\
\text { Total } \\
\text { Provisionals }\end{array}$ & $\begin{array}{c}\text { Documents } \\
\text { Counted } \\
\text { Provisionals }\end{array}$ & $\begin{array}{c}\text { Photo ID- } \\
\text { Related } \\
\text { Provisionals }\end{array}$ & $\begin{array}{c}\text { Photo } \\
\text { ID- } \\
\text { Related } \\
\text { Counted }\end{array}$ & $\begin{array}{c}\text { HAVA } \\
\text { Total } \\
\text { Provisionals }\end{array}$ & $\begin{array}{c}\text { HAVA } \\
\text { Counted }\end{array}$ \\
\hline Adams & 13,231 & 25 & 5 & 24 & 5 & 5 & 2 & 0 & 0 \\
\hline Allen & 148,995 & 345 & 107 & 344 & 114 & 34 & 4 & 2 & 1 \\
\hline Bartholomew & 29,753 & 17 & 2 & 15 & 2 & 6 & 1 & 0 & 0 \\
\hline Benton & 3,686 & 1 & 0 & 1 & 0 & 0 & 0 & 0 & 0 \\
\hline Blackford & 4,838 & 8 & 0 & 8 & 0 & 0 & 0 & 0 & 0 \\
\hline Boone & 28,068 & 26 & 4 & 26 & 4 & 2 & 0 & 0 & 0 \\
\hline Brown & 7,766 & 37 & 4 & 37 & 4 & 6 & 1 & 0 & 0 \\
\hline Carroll & 8,028 & 29 & 10 & 29 & 10 & 2 & 1 & 0 & 0 \\
\hline Cass & 14,484 & 38 & 20 & 38 & 20 & 8 & 2 & 0 & 0 \\
\hline Clark & 47,867 & 196 & 61 & 162 & 21 & 18 & 0 & 3 & 0 \\
\hline Clay & 11,130 & 0 & 0 & 0 & 0 & 0 & 0 & 0 & 0 \\
\hline Clinton & 10,079 & 14 & 0 & 14 & 1 & 1 & 0 & 0 & 0 \\
\hline Crawford & 3,938 & 5 & 3 & NA & NA & NA & NA & NA & NA \\
\hline Daviess & 10,449 & 1 & 1 & 1 & 1 & 1 & 1 & 0 & 0 \\
\hline Dearborn & 22,660 & 14 & 4 & 11 & 3 & 0 & 0 & 0 & 0 \\
\hline Decatur & 10,494 & 3 & 0 & 3 & 0 & 2 & 0 & 0 & 0 \\
\hline DeKalb & 16,594 & 9 & 1 & 9 & 1 & 2 & 0 & 0 & 0 \\
\hline Delaware & 37,231 & 72 & 29 & 72 & 29 & 0 & 0 & 7 & 7 \\
\hline Dubois & 18,973 & 0 & 0 & 0 & 0 & 0 & 0 & 0 & 0 \\
\hline Elkhart & 68,450 & 240 & 52 & 222 & 21 & 16 & 2 & 1 & 0 \\
\hline Fayette & 8,973 & 5 & 3 & 5 & 3 & 2 & 2 & 0 & 0 \\
\hline Floyd & 35,820 & 68 & 8 & 74 & 8 & 11 & 2 & 0 & 0 \\
\hline Fountain & 7,250 & 20 & 8 & 20 & 8 & 1 & 0 & 1 & 1 \\
\hline Franklin & 10,727 & 22 & 5 & 21 & 3 & 7 & 0 & 1 & 1 \\
\hline Fulton & 8,388 & 6 & 0 & 6 & 0 & 2 & 0 & 0 & 0 \\
\hline Gibson & 14,973 & 8 & 0 & 8 & 0 & 0 & 0 & 0 & 0 \\
\hline Grant & 25,738 & 22 & 4 & 24 & 5 & 1 & 0 & 0 & 0 \\
\hline Greene & 13,433 & 0 & 0 & 0 & 0 & 0 & 0 & 0 & 0 \\
\hline Hamilton & 138,252 & 31 & 6 & 31 & 6 & 7 & 0 & 1 & 0 \\
\hline Hancock & 33,073 & 74 & 2 & 74 & 3 & 2 & 1 & 0 & 0 \\
\hline Harrison & 17,942 & 62 & 19 & 54 & 8 & 11 & 3 & 0 & 0 \\
\hline Hendricks & 67,538 & 71 & 3 & 70 & 3 & 7 & 0 & 0 & 0 \\
\hline Henry & 19,413 & 0 & 0 & 2 & 0 & 0 & 0 & 0 & 0 \\
\hline Howard & 37,056 & 70 & 24 & 71 & 16 & 13 & 6 & 3 & 1 \\
\hline Huntington & 16,002 & 2 & 0 & 2 & 0 & 1 & 0 & 0 & 0 \\
\hline
\end{tabular}




\begin{tabular}{|c|c|c|c|c|c|c|c|c|c|}
\hline County & $\begin{array}{l}\text { Total } \\
\text { Ballots }\end{array}$ & $\begin{array}{c}\text { CEB-9 } \\
\text { Total } \\
\text { Provisionals }\end{array}$ & $\begin{array}{c}\text { CEB-9 } \\
\text { Counted } \\
\text { Provisionals }\end{array}$ & $\begin{array}{c}\text { Documents } \\
\text { Total } \\
\text { Provisionals }\end{array}$ & $\begin{array}{c}\text { Documents } \\
\text { Counted } \\
\text { Provisionals }\end{array}$ & $\begin{array}{c}\text { Photo ID- } \\
\text { Related } \\
\text { Provisionals }\end{array}$ & $\begin{array}{c}\text { Photo } \\
\text { ID- } \\
\text { Related } \\
\text { Counted }\end{array}$ & $\begin{array}{c}\text { HAVA } \\
\text { Total } \\
\text { Provisionals }\end{array}$ & $\begin{array}{c}\text { HAVA } \\
\text { Counted }\end{array}$ \\
\hline Jackson & 17,006 & 5 & 1 & 5 & 1 & 1 & 0 & 0 & 0 \\
\hline Jasper & 21,934 & NA & NA & 0 & 0 & 0 & 0 & 0 & 0 \\
\hline Jay & 8,047 & 19 & 2 & 17 & 0 & 0 & 0 & 0 & 0 \\
\hline Jefferson & 13,380 & 19 & 0 & 19 & 0 & 6 & 0 & 1 & 0 \\
\hline Jennings & 10,647 & 30 & 6 & 29 & 5 & 0 & 0 & 0 & 0 \\
\hline Johnson & 58,520 & 14 & 1 & 14 & 1 & 2 & 0 & 0 & 0 \\
\hline Knox & 15,457 & 0 & 0 & 0 & 0 & 0 & 0 & 0 & 0 \\
\hline Kosciusko & 30,507 & 66 & 6 & 66 & 6 & 7 & 0 & 0 & 0 \\
\hline LaGrange & 15,743 & NA & NA & 15 & 0 & 0 & 0 & 0 & 0 \\
\hline Lake & 205,847 & 772 & 93 & 728 & 89 & 55 & 1 & 4 & 1 \\
\hline LaPorte & 44,648 & 74 & 8 & 74 & 8 & 14 & 1 & 0 & 0 \\
\hline Lawrence & 18,239 & 16 & 4 & 15 & 3 & 2 & 0 & 0 & 0 \\
\hline Madison & 53,066 & 61 & 1 & 61 & 0 & 8 & 0 & 0 & 0 \\
\hline Marion & 361,278 & 947 & 120 & 918 & 152 & 79 & 5 & 12 & 2 \\
\hline Marshall & 18,103 & 3 & 1 & 3 & 1 & 2 & 1 & 0 & 0 \\
\hline Martin & 4,890 & 11 & 1 & 11 & 1 & 7 & 1 & 0 & 0 \\
\hline Miami & 12,947 & 5 & 2 & 5 & 2 & 1 & 1 & 0 & 0 \\
\hline Monroe & 57,951 & 198 & 39 & 197 & 1 & 76 & 0 & 7 & 0 \\
\hline Montgomery & 14,744 & 6 & 0 & 6 & 0 & 0 & 0 & 0 & 0 \\
\hline Morgan & 28,735 & 30 & 4 & 30 & 4 & 5 & 1 & 0 & 0 \\
\hline Newton & 5,752 & 3 & 0 & 3 & 0 & 0 & 0 & 0 & 0 \\
\hline Noble & 16,630 & 9 & 1 & 9 & 1 & 1 & 1 & 0 & 0 \\
\hline Ohio & 4,538 & 11 & 3 & 11 & 3 & 4 & 2 & 0 & 0 \\
\hline Orange & 7,966 & 30 & 2 & 30 & 2 & 2 & 0 & 0 & 0 \\
\hline Owen & 8,287 & 6 & 1 & 5 & 1 & 1 & 1 & 0 & 0 \\
\hline Parke & 6,634 & 25 & 10 & 25 & 10 & 2 & 0 & 0 & 0 \\
\hline Perry & 8,046 & 12 & 2 & 12 & 2 & 5 & 0 & 0 & 0 \\
\hline Pike & 6,101 & 10 & 0 & 8 & 0 & 0 & 0 & 0 & 0 \\
\hline Porter & 73,810 & 115 & 26 & 87 & 22 & 12 & 1 & 6 & 2 \\
\hline Posey & 12,461 & 15 & 6 & 15 & 6 & 1 & 0 & 0 & 0 \\
\hline Pulaski & 5,509 & 4 & 3 & 2 & 2 & 0 & 0 & 0 & 0 \\
\hline Putnam & 14,007 & 24 & 4 & 24 & 4 & 3 & 0 & 0 & 0 \\
\hline Randolph & 10,374 & 16 & 1 & 15 & 0 & 3 & 0 & 2 & 0 \\
\hline Ripley & 11,141 & 2 & 0 & 2 & 0 & 0 & 0 & 0 & 0 \\
\hline Rush & 7,150 & 0 & 0 & 0 & 0 & 0 & 0 & 0 & 0 \\
\hline St. Joseph & 111,622 & 101 & 4 & 102 & 4 & 27 & 0 & 2 & 0 \\
\hline Scott & 8,929 & 5 & 0 & 5 & 0 & 1 & 0 & 0 & 0 \\
\hline
\end{tabular}




\begin{tabular}{|c|c|c|c|c|c|c|c|c|c|}
\hline County & $\begin{array}{l}\text { Total } \\
\text { Ballots }\end{array}$ & $\begin{array}{c}\text { CEB-9 } \\
\text { Total } \\
\text { Provisionals }\end{array}$ & $\begin{array}{c}\text { CEB-9 } \\
\text { Counted } \\
\text { Provisionals }\end{array}$ & $\begin{array}{c}\text { Documents } \\
\text { Total } \\
\text { Provisionals }\end{array}$ & $\begin{array}{c}\text { Documents } \\
\text { Counted } \\
\text { Provisionals }\end{array}$ & $\begin{array}{c}\text { Photo ID- } \\
\text { Related } \\
\text { Provisionals }\end{array}$ & $\begin{array}{c}\text { Photo } \\
\text { ID- } \\
\text { Related } \\
\text { Counted } \\
\end{array}$ & $\begin{array}{c}\text { HAVA } \\
\text { Total } \\
\text { Provisionals }\end{array}$ & $\begin{array}{c}\text { HAVA } \\
\text { Counted }\end{array}$ \\
\hline Shelby & 17,063 & 10 & 2 & 10 & 2 & 1 & 0 & 0 & 0 \\
\hline Spencer & 15,662 & 21 & 0 & 22 & 0 & 2 & 0 & 0 & 0 \\
\hline Starke & 8,944 & 27 & 3 & 27 & 3 & 6 & 0 & 0 & 0 \\
\hline Steuben & 13,857 & 25 & 11 & 25 & 11 & 1 & 0 & 0 & 0 \\
\hline Sullivan & 8,485 & 0 & 0 & 0 & 0 & 0 & 0 & 0 & 0 \\
\hline Switzerland & 3,547 & 2 & 0 & 2 & 0 & 0 & 0 & 0 & 0 \\
\hline Tippecanoe & 58,275 & 336 & 12 & 337 & 13 & 21 & 0 & 0 & 0 \\
\hline Tipton & 7,497 & 0 & 0 & 0 & 0 & 0 & 0 & 0 & 0 \\
\hline Union & 3,130 & 0 & 0 & 0 & 0 & 0 & 0 & 0 & 0 \\
\hline Vanderburgh & 73,486 & 350 & 27 & 230 & 28 & 18 & 2 & 76 & 3 \\
\hline Vermillion & 6,750 & 2 & 0 & 2 & 0 & 0 & 0 & 0 & 0 \\
\hline Vigo & 40,357 & 143 & 5 & 97 & 5 & 1 & 0 & 0 & 0 \\
\hline Wabash & 13,185 & 0 & 0 & 0 & 0 & 0 & 0 & 0 & 0 \\
\hline Warren & 3,913 & 0 & 0 & 0 & 0 & 0 & 0 & 0 & 0 \\
\hline Warrick & 24,984 & 18 & 4 & 18 & 4 & 9 & 0 & 0 & 0 \\
\hline Washington & 10,916 & 14 & 1 & 14 & 0 & 12 & 0 & 0 & 0 \\
\hline Wayne & 26,225 & 18 & 8 & 20 & 8 & 13 & 2 & 0 & 0 \\
\hline Wells & 13,098 & 7 & 1 & 8 & 0 & 2 & 0 & 0 & 0 \\
\hline White & 10,082 & 5 & 2 & 5 & 2 & 3 & 2 & 0 & 0 \\
\hline Whitley & 15,207 & 6 & 0 & 6 & 0 & 1 & 0 & 0 & 0 \\
\hline Totals & $2,676,601$ & 5,189 & 813 & 4,869 & 706 & 585 & 50 & 129 & 19 \\
\hline
\end{tabular}


Appendix B

\begin{tabular}{|c|c|c|c|}
\hline County & Male & Female & Undetermined \\
\hline Adams & Kenneth, Zaid & Kelly, Linda, Amber & \\
\hline Allen & $\begin{array}{l}\text { Arlen, Jon, Larry, } \\
\text { Jared, Lawrence, Paul, } \\
\text { Shane, Stephen, } \\
\text { Joshua, James, } \\
\text { Robener Alexander, } \\
\text { William, Branden } \\
\text { Michael }\end{array}$ & $\begin{array}{l}\text { Ashlee Beth, Madison, Sally, } \\
\text { Freda, Darcia, Lucretia, Beverly, } \\
\text { Norma, Josalein Rose, Kayla, } \\
\text { Allison, Diane, Karen, Jana } \\
\text { Renee, Jaquayla, Evelyn, } \\
\text { Artelethea, Doris, Aisha }\end{array}$ & $\begin{array}{l}\text { Tishunna, Chukwemeka, } \\
\text { Guile, Berl }\end{array}$ \\
\hline Bartholomew & Bryce, Hector & Melissa, Tamara, Tracy, Regina & \\
\hline Boone & & Kimberly & Leslie \\
\hline Brown & Steven & $\begin{array}{l}\text { Opal Marie, Naomi, Danielle, } \\
\text { Samantha }\end{array}$ & Ofelda \\
\hline Carroll & & Dorothy, Mary & \\
\hline Cass & $\begin{array}{l}\text { Arthur, Walter, David, } \\
\text { James }\end{array}$ & Mary, Katie, Courtney, Mary & \\
\hline Clark & $\begin{array}{l}\text { Travis, Ronald, David, } \\
\text { Foster Steven, Michael }\end{array}$ & $\begin{array}{l}\text { Christina, Kristina, Jane, Mariah, } \\
\text { Elaine, Patricia, Barbara, Ebony, } \\
\text { Ashley, Erin, Kasandra }\end{array}$ & $\begin{array}{l}\text { Noel, Athesham, Jalese, } \\
\text { Dorlas, Gerry }\end{array}$ \\
\hline Clinton & Clayton & & \\
\hline Daviess & Jeremiah & & \\
\hline Decatur & Michael & Teresa & \\
\hline DeKalb & Chase & Melissa & \\
\hline Delaware & $\begin{array}{l}\text { Nathan, Julian, } \\
\text { Desmond }\end{array}$ & Lori, Megan & Kelly, Nadirah \\
\hline Elkhart & $\begin{array}{l}\text { Ronald, James, Lamar, } \\
\text { Stephen, Travis, } \\
\text { Edward, Douglas, } \\
\text { Paul, Francis }\end{array}$ & $\begin{array}{l}\text { LeAnna, Kim Ann, Dorothy, } \\
\text { Sheryll, Queen, Lela, Julia }\end{array}$ & Sam \\
\hline Fayette & & Linda, Genevieve & \\
\hline Floyd & Edward, Ricky, Keith & $\begin{array}{l}\text { Amelia, Delisa, Catina, Mary, } \\
\text { Acquanitta }\end{array}$ & Stormi, Eyna, Sanford \\
\hline Fountain & & Judy, Mary & \\
\hline Franklin & Thomas, Bradley & $\begin{array}{l}\text { Vanessa, Emily, Lori, Jodie, } \\
\text { Megan, Danette }\end{array}$ & \\
\hline Fulton & & Eileen, Polly & \\
\hline Grant & & Kaynia & \\
\hline Hamilton & $\begin{array}{l}\text { Jared Matthew, } \\
\text { Christopher, Robert, } \\
\text { Chad }\end{array}$ & $\begin{array}{l}\text { Kimberly, Yolanda, Laurie, } \\
\text { Mindy }\end{array}$ & \\
\hline Hancock & Steven & & Verl \\
\hline Harrison & Ivan, Larry & $\begin{array}{l}\text { Tina, Apryl, Latisha, Katherine, } \\
\text { Millie, Marilee, Bonnie }\end{array}$ & \\
\hline Hendricks & Tom, David, Carlos & Tamara, Julie, Michele, Margaret & \\
\hline
\end{tabular}




\begin{tabular}{|c|c|c|c|}
\hline County & Male & Female & Undetermined \\
\hline Howard & Patrick, Larry, Taylor & $\begin{array}{l}\text { Lorretta, Amber, Stacie Lynn, } \\
\text { Lottie Louise, Cheryl, Dionna, } \\
\text { Sheryl, Ruth, Maxine, Sandra, } \\
\text { Wanda, Gabriella }\end{array}$ & Darrion \\
\hline Huntington & & Sherri & \\
\hline Jackson & David & & \\
\hline Jefferson & Fred, Michael, Seth & Lydia, Mary, Sylvia, Erin & \\
\hline Johnson & & Teresa, Mary Jane & \\
\hline Kosciusko & $\begin{array}{l}\text { Troy, Robert, } \\
\text { Christopher, Earl }\end{array}$ & Carolyn, Marilyn, Phyllis & \\
\hline Lake & $\begin{array}{l}\text { James, Gregory, } \\
\text { Phillip, Dennis, Glenn, } \\
\text { Raymond, Tom, Brian, } \\
\text { Wardell, Byron, } \\
\text { Christopher, Michael, } \\
\text { Johnathan, Daniel, } \\
\text { Alex, Benjamin, } \\
\text { Michael }\end{array}$ & $\begin{array}{l}\text { Evelyn, Beverly, Emily, } \\
\text { Jacqueline, Pearleatha, Latoya, } \\
\text { Esther, Theresa, Carolyn, Sylvia, } \\
\text { Delores, Tia, Shayla, Margaret, } \\
\text { Diamond, Diane, Heather, } \\
\text { Rosalie, Alicia, Creconia Tiera, } \\
\text { Kimberly, Edith, Charlotte, } \\
\text { Suzanne, Andrea, Elaine, Crystal, } \\
\text { Lisa, Betty, Jacqueline, Myra, } \\
\text { Heather }\end{array}$ & $\begin{array}{l}\text { Antaneah, Corvette, Avery, } \\
\text { Hariah, Dominique, Shevon, } \\
\text { Angel, Markie, Dorian }\end{array}$ \\
\hline LaPorte & Dewayne, Willie, Joe & $\begin{array}{l}\text { Doris, Christine, Karen, Krystel, } \\
\text { Nora, Josephine, Joanne, Denise }\end{array}$ & San Juana, Conchada, Azania \\
\hline Lawrence & Samuel, Stephen & & \\
\hline Madison & $\begin{array}{l}\text { Ronnie, Tom, Eddie, } \\
\text { Rafael, Andrew, Kaleb }\end{array}$ & Angela, Evevonne & \\
\hline Marion & $\begin{array}{l}\text { Antonio, Cecil, } \\
\text { William, Dane, Brent, } \\
\text { Danny, Donald, } \\
\text { Daniel, Jason, Noah, } \\
\text { Kevin, Donald, Robert, } \\
\text { Keith, Derik, Robert, } \\
\text { Richard, Jay, Ronald, } \\
\text { David, Cody, John, } \\
\text { Ryan, Bryan, James, } \\
\text { Michael, Richard, } \\
\text { Raymond, Direk, } \\
\text { Robert, Timothy, } \\
\text { Robbin, Adrian, } \\
\text { Hayden, Adrian, Deon }\end{array}$ & $\begin{array}{l}\text { Toria, Felisha, Christy, Brittany, } \\
\text { Roberta, Deborah, Lori, Rhonda, } \\
\text { Sable, Kathryn, Lauren, Jan, } \\
\text { Hollon Marie, Re'Nesia, Amber, } \\
\text { Shelia, Ruby, Crystal, Debra, } \\
\text { Mary, Patricia, Julie, Shante, } \\
\text { Lakenya, Carolyn, Elizabeth, } \\
\text { Diane, Heather, Christina, } \\
\text { Deirdre, Christal, Angela, Tiffany, } \\
\text { Emily, Marguerite, Kathy, Anne, } \\
\text { Margaret, Rhoda, Krista, } \\
\text { Elizabeth }\end{array}$ & $\begin{array}{l}\text { Daladien, Akossiwa, Jamie, } \\
\text { Taquila, Treasan, Lee, } \\
\text { Torrey, Kwabena, Latrell, } \\
\text { Dominique, Ajarae, Dorian, } \\
\text { Meredian, Bryen }\end{array}$ \\
\hline Marshall & Auston & Nicole & \\
\hline Martin & $\begin{array}{l}\text { Randy, Charles, Brian, } \\
\text { Travis, Franklin }\end{array}$ & Melinda, Linda & \\
\hline Miami & & Betty & \\
\hline
\end{tabular}




\begin{tabular}{|c|c|c|c|}
\hline County & Male & Female & Undetermined \\
\hline Monroe & $\begin{array}{l}\text { Jeremiah, John, } \\
\text { Anthony, Scott, } \\
\text { Stephen, Matthew, } \\
\text { John, Timothy, Joseph, } \\
\text { John, Joseph, Blair } \\
\text { Christopher, Aaron, } \\
\text { Daniel, Donald, Max, } \\
\text { Daniel, Tyler, Robert, } \\
\text { Brian, Andrew, Devin, } \\
\text { Harold, Andrew, } \\
\text { Thomas, Matthew, } \\
\text { Mason, Dennis, } \\
\text { Steven, Benjamin, } \\
\text { John, Christopher, } \\
\text { Jedd, Chris }\end{array}$ & $\begin{array}{l}\text { Kristin, Kayla, Fernanda, Laura, } \\
\text { Jacqueline, Martha, Carolyn, } \\
\text { Marilyn, Sally, Amanda, Diana, } \\
\text { Nadia, Karen, Madison, Emma, } \\
\text { Christina, Lily, Brittany, Ella, } \\
\text { Chelsea, Nicole, Rachel, Jennifer, } \\
\text { McKenzie, Linda, Nichelle, Erin, } \\
\text { Trisha, Shirley, Grace, Anna, } \\
\text { Pamela, Heather, Jessica, Bernita, } \\
\text { Tierra, Deborah, Kelsey, Celia, } \\
\text { Heidi, Natalie, Brittany, Laura }\end{array}$ & $\begin{array}{l}\text { Toro, Abdelmuezz, Shae, } \\
\text { Sarasopa, Taylor, }{ }^{89} \text { Leslie }\end{array}$ \\
\hline \multicolumn{4}{|l|}{ Montgomery } \\
\hline Morgan & $\begin{array}{l}\text { John, Jay, Darrin } \\
\text { Charles, Garry }\end{array}$ & & Vernes \\
\hline Noble & & Donna & \\
\hline $\begin{array}{l}\text { Ohio-all the } \\
\text { information is } \\
\text { redacted. Not sure } \\
\text { how to proceed }\end{array}$ & & & All names redacted \\
\hline Orange & Jerry & & Naaman \\
\hline Owen & Richard & & \\
\hline Parke & Charles & Kathy & \\
\hline Perry & Herman & Brittney, Robin, Tabitha, Mary & \\
\hline Porter & $\begin{array}{l}\text { Benjamin, Bart, } \\
\text { Joshua, Harold, Gorgi }\end{array}$ & $\begin{array}{l}\text { Melissa, Anne, Marguerite, Paula, } \\
\text { Susan, Diane, Megan, Stephanie, } \\
\text { Brittany, Sheri }\end{array}$ & Zenaida, Terra, Jamie' \\
\hline Posey & & Carolyn & \\
\hline Putnam & Austin, Kevin & Melissa & \\
\hline Randolph & & Natalie, Annette, Tiffani, Nettie & Terry \\
\hline St. Joseph & $\begin{array}{l}\text { Joe, Dennis, John, } \\
\text { Clinton, Ricky, } \\
\text { Charles, Sean, } \\
\text { Timothy, Bob, } \\
\text { Abraham, John, } \\
\text { Ronald, Dane, } \\
\text { Timothy }\end{array}$ & $\begin{array}{l}\text { Nancy, Brigitte, Bettie, Kelsey, } \\
\text { Jodi, Kimbra, Mary Ann, Antonia, } \\
\text { Ana, Katherine, Adrianne, } \\
\text { Valerie, Marian }\end{array}$ & Zayre, Quinn \\
\hline Scott & David & & \\
\hline
\end{tabular}

89. There was a Taylor that was listed as a male in Howard County but that was because there was other evidence in the documents of gender. 


\begin{tabular}{|c|c|c|c|}
\hline County & Male & Female & Undetermined \\
\hline Shelby & & Karen & \\
\hline Spencer & & Faith, Tonya & \\
\hline Starke & Paul & $\begin{array}{l}\text { Marie, Jessica, Ashley, Christina, } \\
\text { Kerrie }\end{array}$ & \\
\hline Steuben & & Teresa & \\
\hline Tippecanoe & $\begin{array}{l}\text { Philip, Thomas, } \\
\text { Thomas, Wayne, } \\
\text { Darrel, Timothy }\end{array}$ & $\begin{array}{l}\text { Tonya, Latisha, Keriann, Barbara, } \\
\text { Natalie, Akina, Gloria, Delores, } \\
\text { Priscilla, Beverly, Susan, Amber, } \\
\text { Monica }\end{array}$ & Fairbee, Quron \\
\hline Vanderburgh & $\begin{array}{l}\text { Christopher, Eric, } \\
\text { John, David, Micahl, } \\
\text { Michael, Andrew, } \\
\text { Bradley, Adam, Kyle, } \\
\text { Kyle, Charles, } \\
\text { Nicholas, Aaron, } \\
\text { Matthew, Jared, Josh, } \\
\text { Michael, Antonio, } \\
\text { James, Travis, Justin, } \\
\text { Matt, Gary, Zachary, } \\
\text { Kenny, Gary, Keivon, } \\
\text { Kevin, Matthew, } \\
\text { Gerald, Corey, James, } \\
\text { Aaron, Adrian }\end{array}$ & $\begin{array}{l}\text { Nora, Melissa, Stacey, Sandra, } \\
\text { Dolores, Naquasha, Mary, } \\
\text { Kameelah, Monica, Heather, } \\
\text { Morella, Krystal, Jacinda, Sarah, } \\
\text { Sharon, Janet, Kathryn, Abby, } \\
\text { Kelli, Laura, Carley, Terri, Stacey, } \\
\text { Ann, Dorothy, Antoinnette, } \\
\text { Caitlin, Brenda, Lauren, Melissa, } \\
\text { Ellen, Tiffany, Rosemarie, } \\
\text { Katherine, Ashley, Lisa, Deborah, } \\
\text { Darla, Samantha, Myra, Tania, } \\
\text { Pamela, Teresa, Jessica, Lesa, } \\
\text { Dorothy, Tia, Jessica, Michele, } \\
\text { Jesusita, Ashlynn, Linda, } \\
\text { Michelle, Jennifer, Mary, Karen, } \\
\text { Lisa, Elizabeth, Amanda }\end{array}$ & \\
\hline Vigo & & Crystal & \\
\hline Warrick & Dennis, Robert, Darrell & $\begin{array}{l}\text { Tamara, Amy, Brittany, Carol, } \\
\text { Leah, Mary }\end{array}$ & \\
\hline Washington & $\begin{array}{l}\text { Joseph, William, } \\
\text { Allen, Donald, Jeff, } \\
\text { Vance }\end{array}$ & $\begin{array}{l}\text { Geneva, Lindsey, Maggie, } \\
\text { Dorothy, Michelle, Cora }\end{array}$ & \\
\hline Wayne & $\begin{array}{l}\text { Douglas, Ralph, Miles, } \\
\text { Aaron, Jesse }\end{array}$ & $\begin{array}{l}\text { Donna, Phoebe, Stacy, Charlette, } \\
\text { Megan, Kathleen, Kimberly }\end{array}$ & Leslie \\
\hline Wells & Francis & Jeanelle & \\
\hline White & Marlon & Lizbeth, Elizabeth & \\
\hline Whitley & Jared & & \\
\hline
\end{tabular}

